\title{
The benefits of peer-led teaching in medical education
}

This article was published in the following Dove Press journal:

Advances in Medical Education and Practice

31 May 2016

Number of times this article has been viewed

\section{Silvia Allikmets' \\ Jasper P Vink ${ }^{2}$}

'King's College London School of Medicine, ${ }^{2}$ Imperial College London School of Medicine, London, UK

Correspondence: Silvia Allikmets King's College London School of Medicine, London, 165 Great Dover Street, SEI 4XA, London, UK Email silvia.allikmets@kcl.ac.uk

\section{Dear editor}

In their article, Fujiwara et al ${ }^{1}$ discussed the effect of peer-led training of basic life support in the education of medical students. As the training of medical students is a continuously dynamic and developing field, such statistically significant information is useful to consider when improving medical teaching programs. While we agree with the conclusions drawn by Fujiwara et al, ${ }^{1}$ we suggest that peer-led teaching is superior to conventional (eg, professor-led) learning methods in medical education, providing benefits for students, tutors, and their faculties.

Peer-led teaching has been shown to be beneficial for student teachers and learners alike, as well as for an educational organization as a whole. ${ }^{2,3}$ There are a multitude of advantages of peer teaching in medical education, thoroughly reviewed by Ten Cate and Durning. ${ }^{2}$ We present three main groups of beneficiaries of peer-led teaching and suggest the evidence for why peer-led teaching could be considered more beneficial than professional-led teaching.

First, peer-led teaching is beneficial for students, as it provides a comfortable learning environment to explore and develop understanding of different fields of medicine. For example, students are more likely to discuss ethical dilemmas with peers rather than professors, ${ }^{4}$ as they may feel less intimidated. Furthermore, retention and application of knowledge, ${ }^{5}$ as well as academic performance, ${ }^{6}$ have been shown to improve significantly by peer-led teaching compared to lecture-style teaching. These improvements may be explained by increased motivation in students exposed to peerled teaching, as it provides an interesting, alternative method for studying, as well as allows for a certain degree of socialization between peers and the establishment of role models. ${ }^{2}$ Therefore, students gain academic, motivational, and social benefits from peer-led teaching.

Second, peer-led teaching provides significant benefits for the student tutors themselves who are involved in the educational process. Placing student tutors in a position of responsibility to teach others provides excellent opportunities to enhance leadership, presentation, and organizational skills, all of which are key elements of clinical practice. Furthermore, teaching exposes the tutor to giving and receiving feedback, both of which are important for improving one's own learning and confidence. ${ }^{7}$ These are transferable skills that will ultimately improve medical students' performance in the clinical workforce. Additionally, according to Krych et al, ${ }^{8} 92 \%$ of first-year medical 
students found that reciprocal peer teaching methods in gross anatomy teaching improved their communication skills. This is a significant finding, as communication is considered to be vital to the medical profession and has been shown to impact patient satisfaction and adherence to medical treatment. ${ }^{9}$ Thus, student tutors benefit by developing leadership, emotional and communication skills.

Finally, peer-led teaching has benefits for medical faculties or health care organizations themselves. Not only does peer-led teaching alleviate the pressure of organizing tutors, schedules, and locations for the students but it is also an effective way to sustain medical training programs where resources have become scarce. ${ }^{2}$ At a time where the UK National Health Service is faced with a significant funding gap and resource constraints, ${ }^{10}$ peer-led teaching should be considered a cost-effective method of providing adequate education. Therefore, organizations would benefit from implementing student-led teaching, as it allows for the delegation of responsibility, more efficient resource allocation and, ultimately, contributing to the development of a sustainable health care system.

To conclude, while we agree with Fujiwara et $\mathrm{al}^{1}$ that peer-led teaching of medical education is advantageous and effective, we suggest that peer-led teaching of medical education can be even more effective than professional-led teaching in certain aspects of medical education. Ultimately, we believe it is important to establish a stronger focus on peer-led teaching in medical curricula and, therefore, medical education programs should be adjusted to incorporate this for the benefit of the students, student teachers, and organizations alike.

\section{Disclosure}

The authors report no conflicts of interest in this communication.

\section{References}

1. Fujiwara T, Nishimura M, Honda R, et al. Comparison of peer-led versus professional-led training in basic life support for medical students. $A d v$ Med Educ Pract. 2011;2:187-191.

2. Ten Cate O, Durning S. Peer teaching in medical education: twelve reasons to move from theory to practice. Med Teach. 2007;29: 591-599.

3. Yu TC, Wilson NC, Singh PP, Lemanu DP, Hawken SJ, Hill AG. Medical students-as-teachers: a systematic review of peer-assisted teaching during medical school. Adv Med Educ Pract. 2011;2:157-172.

4. Hindmarch T, Allikmets S, Knights F. A narrative review of undergraduate peer-based healthcare ethics teaching. Int J Med Educ. 2015;6: 184-190.

5. Abedini M, Mortazavi F, Javadinia SA, Moonaghi HK. A new teaching approach in basic sciences: Peer assisted learning. Procedia Soc Behav Sci. 2013;83:39-43.

6. Wong JG, Waldrep TD, Smith TG. Formal peer-teaching in medical school improves academic performance: the MUSC supplemental instructor program. Teach Learn Med. 2007;19:216-220.

7. Burgess AW, Roberts C, Black KI, Mellis C. Senior medical student perceived ability and experience in giving peer feedback in formative long case examinations. BMC Med Educ. 2013;13(1):1-5.

8. Krych AJ, March CN, Bryan RE, Peake BJ, Pawlina W, Carmichael SW. Reciprocal peer teaching: Students teaching students in the gross anatomy laboratory. Clin Anat. 2005;18(4):296-301.

9. Stewart M, Brown JB, Boon H, Galajda J, Meredith L, Sangster M. Evidence on patient-doctor communication. Cancer Prev Control. 1999;3;25-30.

10. Roberts A, Marshall L, Charlesworth A. A decade of austerity? The funding pressures facing the NHS from 2010/11 to 2021/22 2012 . Available from: http://www.nufeldtrust.org.uk/publications/decadeausterity-funding-pressures-facing-nhs. Accessed 1 March, 2016.

Dove Medical Press encourages responsible, free and frank academic debate. The content of the Advances in Medical Education and Practice 'letters to the editor' section does not necessarily represent the views of Dove Medical Press, its officers, agents, employees, related entities or the Advances in Medical Education and Practice editors. While all reasonable steps have been taken to confirm the content of each letter, Dove Medical Press accepts no liability in respect of the content of any letter, nor is it responsible for the content and accuracy of any letter to the editor.

\section{Publish your work in this journal}

Advances in Medical Education and Practice is an international, peerreviewed, open access journal that aims to present and publish research on Medical Education covering medical, dental, nursing and allied health care professional education. The journal covers undergraduate education, postgraduate training and continuing medical education including emerging trends and innovative models linking education, research, and health care services. The manuscript management system is completely online and includes a very quick and fair peer-review system. Visit http://www.dovepress.com/testimonials.php to read real quotes from published authors. 